\title{
The meaning of democracy vs. ideology
}

\author{
Agnieszka Grażul-Luft \\ Faculty of Humanities and Social Sciences, Mazovian State University in Płock, Poland \\ https://doi.org/10.36505/ExLing-2020/11/0024/000439
}

\begin{abstract}
The subject of research refers to changes in the meaning of the lexeme democracy over the past 20 years, noticeable in texts from the Polish press of specific ideological profile. The authors of press texts often expand the meaning, saturating it with emotions and evaluating. On the basis of examples of using a word in texts, there have been definitional sentences created testifying to the extensions of meanings comparing to those found in the Polish language presented in dictionaries. The analysis demonstrates that the understanding of the word democracy depends on the political context and is subject to modifications resulting from ideological entanglements.
\end{abstract}

Keywords: ideology, meaning, lexeme, democracy, political discourse

\section{Introduction}

Ideology, influencing the shaping of public life and emotional attitudes towards politics, does influence the language. The authors of press texts often expand the meaning, saturating it with emotions and evaluations. The use of language is influenced by the context, which leads to extensions and changes of meaning (e.g. Cruse 2001, Yule 1994, 1996, Brown 1998). The aim of the research was to analyze the differentiation of the meaning of the lexeme democracy in the political discourse on the basis of contextual uses in writings classified as rightwing and left-wing, so as to answer the question whether and to what extent ideology influences the shaping of meaning.

The analysis of the meanings of lexemes-concepts has been focused around the issue of the dyad, in this case created from the antithetical concepts of the right- the left. Although the dichotomy is the tool right for describing the socio-political realities of the turn of the century, in the case of the following research it is not the most important what substantive content the two concepts entail. What is important is that they constitute the two opposing sides of the political conflict. The opposition of those categories represents the typical dyadic mindset (Bobbio 1996). Binary nature has become the basis for the selection of press titles and the very description of changes in meaning. Even though the political situation in Poland in the second decade of the 21st century has changed so much that the opposition between the right-wing and the leftwing has been relegated to the background while the opposing sides of the political conflict created two parties located within the right-wing and the center, the dichotomous context has not lost any of its topicality.

ExLing 2020: Proceedings of $11^{\text {th }}$ International Conference of Experimental Linguistics, 12-14 October 2020, Athens, Greece 


\section{Methodology}

The study was conducted in three stages. The first main stage covered the analysis of press texts of 1999-2001, i.e. a decade after the political transformation in Poland. The extensions of the lexeme democracy observed and the conclusions of the main analysis were then confronted with the press material of 2011-2013 (stage 2) and 2017-2019 (stage 3) in order to answer the question regarding the degree of consolidation of the phenomena observed in the Polish language.

The research in the first stage covered six Polish newspapers and magazines: three identified as right-wing and three as left-wing ones. There were excerpts made in journalistic texts to gather examples of using the lexeme democracy. The analysis of changes and semantic extensions was preceded by a review of definitions from several dictionaries of the Polish language. In the description of changes and semantic extensions, the basic unit of definition are not isolated features, but sentences. That type of method allowed the users of the language to understand the lexeme from their subjective point of view. In the second and third stages, there were texts from four (two right-wing and two left-wing) of the six originally selected press titles analyzed as the other two have disappeared from the press market.

As a result of the excerption in the first stage, there were 179 examples of the use of the word democracy collected (in the form of quotations). The frequency of the lexeme usage varied in individual press titles (e.g. due to the fact that they included dailies, weeklies and a monthly). In the research of stages II and III it was assumed that 100-120 citations containing examples of using the democracy lexeme would be collected to achieve the goal assumed. The material was analyzed in terms of the topicality of the changes and semantic extensions described in the implementation of the first stage.

\section{Results}

Basing on the analysis of the contextual use of the lexeme democracy, there were defining elements created absent from dictionary definitions. The meaning of the lexeme in contexts is evaluated and is to a significant degree subject to ideological manipulation.

The key to understanding the lexeme democracy seems to be the division between the ideal and the reality (Dahl 1995). In the material analyzed that specific duality is the basis for thinking about democracy. On one hand, it is the ideal which in Poland was hard to achieve, for which we fought. On the other hand, the ordinary everyday life of our democracy leaves much to be desired.

Both in texts of right-wing and left-wing magazines it is emphasized that democracy is the system with certain values and principles binding. They are juxtaposed with the opinions on actual democracy that does not meet the expectations. On the basis of the texts analyzed, real democracy can be described by means of definitional sentences. 
'Democracy is a system caring just for the interests of the ruling class'

Although democracy is assumed to be the power of the people, when the representatives who exercise power are elected, it ceases to be the system serving the general public. What then becomes of importance is the wellbeing of those in power often achieved at the expense of the society. The feature is considered independent of the political profile of the ruling ones.

Democracy is the system beneficial only to those who managed to get rich' This explication, like the one presented above, is based on the opposition, the dyad. In the former sense, the contrast concerned those in power and the rest of the citizens. Here the opposition is formed between the capitalists (all those who have managed to get rich under the new system) and the rest of society.

'Democracy is a system whose disadvantage is that all citizens have the right to vote'

There is a paradox in this sense. The freedom of choice and the exercise of power by all citizens thanks to voting is a kind of cornerstone of democracy, which the society is highly proud of. However, it has become a curse. Democratic practice seems far from ideal, and in the opinion of the writers not all citizens possess the appropriate predispositions to make responsible choices. Another problem is that the right to vote by all citizens does not guarantee that the elected government or the adopted law is in line with the will of the majority (which is the essence of democracy), as too few people participate in the elections.

'Democracy is a system under threat'

The texts analyzed show that there are numerous dangers to democracy, including, for example, internal political conflicts.

'Democracy poses a threat'

The sense of threat results from the basic principles of the functioning of democracy, it seems obvious to the writers, however, they do not specify what to fear.

The semantic extensions presented found their confirmations in the texts analyzed in stages II and III.

\section{Conclusions}

According to press analyses, Polish democracy turns out to be actual antidemocracy. In the material gathered, there are few statements indicating that Polish citizens are satisfied with the shape of democracy. Citizens are happy that there is democracy in Poland at all, but are still worried regarding its quality. 
The view that there is significant discrepancy between ideal and real democracy unites all sides of the political scene. They indicate the same negative features and accompanying phenomena. Still, it is clear that the assessment of the functioning of democracy in Poland depends on which side of the political conflict is in power. The state of democracy in Poland is assessed higher when the authors of the texts are on the same side of the political conflict as the ruling party. After the power shift, there are changes in the attitude of the writers noticeable immediately.

At the same time, each side displays a certain more or less precise vision of ideal democracy. In that matter, there are ideological divisions coming to life and imaginary democracies taking different shapes depending on their views. The left-wing contests, for example, the xenophobic right-wing movement associated with extreme nationalism. The right wing, on the other hand, is far, in its perception of a democratic system, from, for example, the extreme leftwing connection of democracy with socialism.

In the press basing on ideological message, lexemes become a tool of persuasion. With the use of conversational implicatures, the expression democracy, which does not hold definitional evaluative features, gains axiological character, the result of which are extensions and semantic changes.

\section{References}

Bobbio, N. 1996. Left and Right. The Significance of a Political Distinction. Cambridge, Polity Press.

Brown, G. 1998. Context creation in discourse understanding. In Malmkjaer, K, Williams, J. (eds.) 1998, Context in Language Learning and Language Understanding, 171-193. Cambridge, Cambridge University Press.

Cruse, D. A. 2001. The Lexicon. In Aronoff, M., Rees-Miller J. (eds.) 2001, The Handbook of Linguistics. Oxford, Blackwell Publishing.

Dahl, R. 1995. Demokracja i jej krytycy. Kraków, Znak.

Yule, G. 1994. The study of language. Cambridge, Cambridge University Press.

Yule, G. 1996. Pragmatics. Oxford, Oxford University Press. 